\title{
Pengaruh Profitabilitas, Ukuran Perusahaan, Debt Default dan Audit Tenure terhadap Opini Audit Going Concern
}

Determinants of

Manufacturer's

Going Concern

Audit Opinions

\author{
Suryani \\ Program Studi Akuntansi, Universitas Budi Luhur \\ Jakarta, Indonesia \\ E-Mail: suryani@budiluhur.ac.id
}

\begin{abstract}
Going concern audit opinion is an opinion given by an independent auditor to a company when doubts are found whether the company can maintain its business continuity in the future. This study aims to analyze the effect of profitability, company size, debt default, and audit tenure on going concern audit opinion. The population used in this study were 170 manufacturing companies listed on the Indonesia Stock Exchange for the period 2015-2019 by using the purposive sampling method, obtained a sample of 43 companies that have met the sample selection criteria. The method of analysis used is logistic regression with a significant level of 5\% (0.05) and using an analysis tool in the form of SPSS version 20.0. The results showed that profitability and firm size had a negative effect on going concern audit opinion, debt default had a positive effect on going concern audit opinion, while audit tenure had no effect on going concern audit opinion.
\end{abstract}

Keywords: profitability; size; debt default; audit tenure; going concern audit opinion

\section{PENDAHULUAN}

Dalam memutuskan kebijakan yang akan dijalankan biasanya pihak manajemen, pemegang saham maupun pihak diluar perusahaan akan menggunakan informasi berupa data yang disajikan dalam laporan keuangan. Terhadap perusahaan go publik, laporan keuangan yang disubmit dan dipublikasikan ke publik harus menggunakan laporan keuangan yang telah dilakukan audit oleh auditor independen pada Kantor Akuntan Publik (KAP), tujuan dari ketentuan ini yaitu agar laporan keuangan yang diterima publik sudah menyajikan data secara wajar serta bebas dari salah saji. Dengan melihat informasi pada data yang ada di laporan keuangan tersebut dapat diketahui kondisi keuangan perusahaan termasuk juga yang berkaitan dengan keberlangsungan usahanya (going concern). Informasi mengenai keberlangsungan usaha sangat penting diketahui bagi pengguna laporan keuangan khususnya bagi manajemen perusahaan, pemegang saham maupun calon investor karena selain untuk memperoleh laba yang maksimal, mempertahankan keberlangsungan usaha merupakan tujuan jangka panjang perusahaan.

Saat auditor independen mendapatkan keraguan bahwa perusahaan mampu untuk dapat mempertahankan keberlangsungan usaha dalam jangka waktu dua belas bulan kedepan maka auditor dapat mempertimbangkan untuk menambahkan opini audit tentang going concern perusahaan yang dinyatakan dibagian paragraf penjelas dalam laporan auditor independen (Sari, 2020). Penerimaan opini dengan penjelas terkait going concern perusahaan merupakan signal negatif yang berkaitan penilaian investor terhadap perusahaan sehingga penting untuk meneliti tentang apa saja yang dapat menjadikan pertimbangan auditor independen dalam memberikan opini audit going concern perusahaan (OAGC).

Perusahaan yang masuk kedalam sektor manufaktur merupakan perusahaan dengan kuantitas terbanyak di Bursa Efek Indonesia (BEI). Selama 2015-2019 perusahaan

\section{JIAKES}

$$
\begin{array}{r}
\text { Jurnal Ilmiah Akuntansi } \\
\text { Kesatuan } \\
\text { Vol. } 8 \text { No. 3, 2020 } \\
\text { pg. 245-252 } \\
\text { IBI Kesatuan } \\
\text { ISSN 2337 - 7852 } \\
\text { E-ISSN 2721 - 3048 }
\end{array}
$$


Determinants of Manufacturer's Going Concern Audit Opinions

246 manufaktur yang mendapatkan opini audit going concern sebanyak 5 perusahaan yaitu PT. Asia Pacific Fibers Tbk (POLY), PT. Fajar Surya Wisesa Tbk (FASW), PT. Langgeng Makmur Industri Tbk (LMPI), PT. Yanaprima Hastapersada Tbk (YPAS) dan PT. Indo Acidatama Tbk (SRSN).

Banyak hal yang dapat dapat menjadi penyebab auditor independen memberi OAGC terhadap perusahaan. Berdasarkan observasi penulis terhadap penelitian sebelumnya bahwa profitabilitas, ukuran perusahaan, debt default dan audit tenure merupakan faktor yang berpengaruh terhadap opini audit going concern. Profitabilitas menjadi acuan ketika menilai seberapa efektif manajemen mengelola perusahaan. Profitabilitas salah satunya dapat dilihat dari Return On Asset (ROA), ROA yang positif menandakan perusahaan mampu memperoleh laba dengan sumber daya aset yang dimilikinya. Semakin besar profitabilitas perusahaan artinya semakin efektif manajemen mengelola perusahaan untuk menghasilan laba sehingga akan pemberian opini audit yang berkaitan dengan going concern dari auditor independen akan semakin kecil. Hasil penelitian Indriastuti (2016), Rahman dan Ahmad (2018) serta Irwanto dan Tanusdjaja (2020) membuktikan terdapat pengaruh dari profitabilitas terhadap OAGC, sebaliknya Fitriani dan Asiah (2018) membuktikan tidak ada pengaruh dari profitabilitas terhadap OAGC.

Ukuran perusahaan dapat menggambarkan besar atau kecilnya perusahaan yang biasanya ditentukan berdasarkan jumlah asset, penjualan atau kapitalisasi pasar. Perusahaan besar dianggap lebih mampu untuk mempertahankan usahanya dimasa mendatang dibandingkan perusahaan kecil karena mereka memiliki sumber daya yang lebih banyak dan lebih berkualitas dibandingkan perusahaan kecil. Hasil penelitian Idyantari \& Putri (2011) membuktikan ada pengaruh dari ukuran perusahaan terhadap OAGC, sebaliknya Fadrul dan Wijaya (2018) membuktikan tidak ada pengaruh dari ukuran perusahaan terhadap OAGC.

Debt default merupakan suatu kondisi dimana perusahaan tidak mampu melunasi hutang atau bunganya sesuai dengan jatuh temponya. Debt default dapat mengindikasikan adanya kemungkinan perusahaan tidak dapat melanjutkan usahanya dimasa mendatang sehingga hal ini bisa menjadi dasar auditor independen untuk memberikan opini audit terkait dengan going concern. Hasil penelitian Izazi dan Arfianti (2019), Dewi dan Latrini (2018) serta Kesumojati, Widyastuti dan Darmansyah (2017) yang membuktikan bahwa ada pengaruh dari debt default terhadap OAGC, sebaliknya Putri, Hardiwinoto dan Alwiyah (2018) membuktikan bahwa tidak ada pengaruh dari debt default terhadap OAGC.

Faktor lainnya yang dianggap berpengaruh adalah audit tenure yang menggambarkan seberapa lama perikatan audit dilakukan oleh perusahaan terhadap KAP yang sama secara berturut-turut. Semakin lama auditor yang sama menangani audit suatu perusahaan yang sama maka pengetahuan dan pemahaman auditor terhadap bisnis serta risiko perusahaan akan semakin mendalam sehingga lebih meyakinkan auditor untuk memberikan opini audit yang berkaitan dengan going concern apabila terjadi hal-hal yang memungkinkan keberlangsungan usaha terganggu. Hasil penelitian Ariska, Maslichah dan Afifudin (2019) yang membuktikan bahwa ada pengaruh audit tenure terhadap OAGC, sebaliknya Putri dan Fettry (2017) membuktikan bahwa tidak ada pengaruh audit tenure terhadap OAGC.

Hasil penelitian terdahulu yang tidak konsisten menarik untuk meneliti lagi tentang faktor yang memberikan kontribusi kepada auditor independent untuk memberikan opini audit terkait going concern perusahaan. Diharapkan hasil penelitian ini akan berkontribusi untuk pengembangan teori terkait OAGC dan dapat dijadikan referensi bagi peneliti selanjutnya.

\section{METODOLOGI PENELITIAN}

Perusahaan sektor manufaktur yang terdaftar di Bursa Efek Indonesia tahun 20152019 dijadikan sebagai populasi dalam penelitian ini. Metode purposive sampling 
digunakan untuk melakukan seleksi dalam penentuan sampel. Data sekunder berupa laporan keuangan dari perusahaan manufaktur diperoleh peneliti dengan cara mendownload pada website resmi BEI yaitu www.idx.go.id , tahun pengamatan yaitu 2015-2019. Opini audit going concern dipilih sebagai variabel dependen sedangkan Profitabilitas, Ukuran Perusahaan, Debt Default dan Audit Tenure dipilih sebagai variabel independen.

Data dalam penelitian ini di analisis menggunakan metode regresi logistik yang digunakan untuk mengetahui seberapa besar probabilitas tejadinya variabel dependen dapat diprediksi oleh variabel independen yang digunakan. Dalam teknik analisis regresi logistik tidak dilakukan uji normalitas dalam proses analisis data pada variabel bebasnya (Ghozali, 2016: 321).

Adapun model regresi yang digunakan sebagai berikut:

$$
\operatorname{Ln} \frac{P(Y)}{1-P(Y)}=\alpha+\beta 1 \mathrm{X} 1+\beta 2 \mathrm{X} 2+\beta 3 \mathrm{X} 3+\beta 4 \mathrm{X} 4
$$

Keterangan :

$$
\begin{aligned}
& \mathrm{P}(\mathrm{Y}) \quad=\text { Opini audit going concern } \\
& \alpha=\text { Koefisien konstanta } \\
& \boldsymbol{\beta} 1 \boldsymbol{\beta} 2 \boldsymbol{\beta} 3 \boldsymbol{\beta} 4=\text { Koefisien regresi } \\
& \mathrm{X} 1=\text { Profitabilitas } \\
& \mathrm{X} 2=\text { Ukuran perusahaan } \\
& \mathrm{X} 3=\text { Debt default } \\
& \mathrm{X} 4 \quad=\text { Audit tenure } \\
& \in \quad=\text { Error }
\end{aligned}
$$

\section{Pengembangan Hipotesis \\ Pengaruh Profitabilitas terhadap Opini Audit Going Concern}

Penggunaan rasio profitabilitas bertujuan untuk mengetahui sejauh mana perusahaan dapat menghasilkan laba menggunakan asset yang dimilikinya. Semakin tinggi kemampuan perusahaan untuk menghasilkan laba juga mengukur efektifitas manajemen perusahaan sehingga kemungkinan pemberian opini audit going concern oleh auditor independen akan semakin kecil. Pernyataan diatas didukung oleh penelitian yang dilakukan oleh Indriastuti (2016), Rahman dan Ahmad (2018) serta Irwanto dan Tanusdjaja (2020) yang membuktikan bahwa ada pengaruh negatif profitabilitas terhadap opini audit going concern. Oleh karena itu diajukan hipotesis pertama yaitu :

$\mathrm{H}_{1} \quad$ : Profitabilitas berpengaruh negatif terhadap Opini Audit Going Concern

\section{Pengaruh Ukuran Perusahaan terhadap Opini Audit Going Concern}

Ukuran perusahaan salah satunya dapat dilihat dari seberapa besar asset yang dimilikinya. Semakin besar asset yang dimiliki perusahaan maka dianggap perusahaan lebih mampu mengatasi setiap permasalahan yang timbul dengan didukung oleh sumber daya yang dimilikinya. Kepercayaan publik terhadap perusahaan besar juga lebih tinggi dibandingkan dengan perusahaan kecil sehingga kemungkinan untuk mendapatkan opini audit going concern semakin kecil. Pernyataan diatas didukung oleh penelitian yang dilakukan oleh Widyantari \& Putri (2011) yang membuktikan bahwa ada pengaruh negatif ukuran perusahaan terhadap opini audit going concern. Oleh karena itu diajukan hipotesis kedua yaitu :

$\mathrm{H}_{2} \quad$ : Ukuran Perusahaan berpengaruh negatif terhadap Opini Audit Going Concern

\section{Pengaruh Debt Default terhadap Opini Audit Going Concern}

Debt default merupakan suatu kondisi kegagalan debitur dalam memenuhi kewajiban (hutang) beserta bunganya sampai pada jangka waktu jatuh temponya (Dewi dan Latrini, 2018). Ketika perusahaan mengalamai kegagalan dalam memenuhi kewajibannya itu merupakan salah satu kondisi dimana perusahaan diindikasikan menanggung kesulitan 
Determinants of Manufacturer's Going Concern Audit Opinions

keuangan yang pada akhirnya dapat menimbulkan rasa keraguan auditor terhadap keberlangsungan usaha perusahaan dimasa mendatang sehingga hal ini dapat meningkatkan kemungkinan auditor independen untuk memberikan opini audit going concern. Pernyataan ini didukung dengan hasil penelitian Izazi dan Arfianti (2019) yang membuktikan bahwa ada pengaruh positif debt default terhadap opini audit going concern. Oleh karena itu diajukan hipotesis ketiga yaitu :

$\mathrm{H}_{3} \quad$ : Debt Default berpengaruh positif terhadap Opini Audit Going Concern

\section{Pengaruh Audit Tenure terhadap Opini Audit Going Concern}

Audit tenure merupakan jangka waktu penugasan jasa audit oleh perusahaan kepada KAP yang sama secara berturut-turut yang dapat dihitung dengan jumlah satuan tahun perikatan audit yang dilaksanakan. Semakin panjang hubungan masa perikatan audit, dengan itu auditor akan semakin memahami karakteristik perusahaan dengan memperhatikan kondisi perusahaan pada tahun-tahun sebelumnya. Ketika terjadi suatu kondisi dimana perusahaan diragukan kemampuannya untuk dapat melanjutkan usahanya dimasa mendatang maka auditor akan tidak ragu untuk memberikan opini audit going concern. Pernyataan ini didukung dengan hasil penelitian Ariska, Maslichah dan Afifudin (2019) yang membuktikan bahwa ada pengaruh positif audit tenure terhadap opini audit going concern. Oleh karena itu diajukan hipotesis keempat yaitu :

$\mathrm{H}_{4} \quad$ : Audit Tenure berpengaruh positif terhadap Opini Audit Going Concern

\section{HASIL DAN PEMBAHASAN}

\section{Deskripsi Sampel Penelitian}

Sampel ditentukan menggunakan proses seleksi berdasarkan kriteria yang telah ditentukan seperti dalam Tabel berikut :

Tabel 1. Kronologis Perolehan Data Sampel Penelitian

\begin{tabular}{|c|c|}
\hline Kriteria & $\begin{array}{c}\text { Jumlah } \\
\text { Perusahaan }\end{array}$ \\
\hline Perusahaan manufaktur terdaftar di BEI pada tahun 2015-2019 & 170 \\
\hline Perusahaan yang tidak mempublikasikan laporan keuangan secara & \\
\hline lengkap selama periode $2015-2019$ & $(100)$ \\
\hline Perusahaan yang menggunakan mata uang asing & $(27)$ \\
\hline Jumlah perusahaan yang menjadi sampel & 43 \\
\hline Jumlah data observasi (43 perusahaan x 5 tahun pengamatan) & 215 \\
\hline
\end{tabular}

Sumber: $w w w$. idx.co.id (data diolah penulis )

\section{Analisis Statistik Deskriptif}

Analisis ini berguna memberikan gambaran nilai minimum, maksimum dan rata-rata untuk variabel profitabilitas, ukuran perusahan dan audit tenure. Sedangkan untuk variabel opini audit going concern dan debt default digambarkan perolehan frekuensi perolehan seperti yang disajikan dalam tabel berikut ini :

Tabel 2. Hasil Analisis Deskriptif Profitabilitas, Ukuran Perusahaan dan Audit TenureTahun 2015-2019

\begin{tabular}{|l|r|r|r|}
\hline & $\begin{array}{c}\text { Profitabilitas } \\
\mathrm{X}_{1}\end{array}$ & $\begin{array}{r}\text { Ukuran Perusahaan } \\
\mathrm{X}_{2}\end{array}$ & $\begin{array}{c}\text { Audit Tenure } \\
\mathrm{X}_{4}\end{array}$ \\
\hline Minimal & $-0,1073$ & 19,2586 & 1 \\
\hline Maximal & 0,9210 & 33,4330 & 5 \\
\hline Rata-Rata & 0,0898 & 28,8196 & 2,372 \\
\hline $\mathrm{N}$ & 215 & 215 & 215 \\
\hline
\end{tabular}

Sumber: data sekunder yang diolah, 2020 
Variabel profitabilitas, ukuran perusahaan dan audit tenure memiliki nilai minimal masing-masing sebesar $-0,1073 ; 19,2586 ; 1$, nilai maksimal masing-masing sebesar 0,$9210 ; 33,4330 ; 5$, dan nilai rata - rata masing-masing sebesar 0,0898; 28,8196; dan 2,372 .

Tabel 3. Hasil Analisis Deskriptif Opini Audit Going Concern Tahun 2015-2019

\begin{tabular}{|c|c|c|c|c|c|}
\hline Keterangan & $\mathbf{2 0 1 5}$ & $\mathbf{2 0 1 6}$ & $\mathbf{2 0 1 7}$ & $\mathbf{2 0 1 8}$ & $\mathbf{2 0 1 9}$ \\
\hline OAGC & 41 & 42 & 42 & 40 & 40 \\
\hline Non OAGC & 2 & 1 & 2 & 3 & 3 \\
\hline
\end{tabular}

Sumber: data sekunder yang diolah, 2020

Berdasarkan tabel diatas dapat dilihat bahwa selama tahun 2015 - 2019 jumlah perusahaan yang mendapatkan opini audit going concern masing-masing sebanyak $2 ; 1 ; 2 ; 3 ; 3$ perusahaan.

Tabel 4. Hasil Analisis Deskriptif Debt Default Tahun 2015-2019

\begin{tabular}{|c|c|c|c|c|c|}
\hline Keterangan & $\mathbf{2 0 1 5}$ & $\mathbf{2 0 1 6}$ & $\mathbf{2 0 1 7}$ & $\mathbf{2 0 1 8}$ & $\mathbf{2 0 1 9}$ \\
\hline DD & 7 & 16 & 16 & 15 & 16 \\
\hline Non DD & 36 & 27 & 27 & 28 & 27 \\
\hline
\end{tabular}

Sumber : data sekunder yang diolah, 2020

Berdasarkan tabel diatas dapat dilihat bahwa selama tahun 2015 - 2019 jumlah perusahaan yang mengalami kondisi debt default masing-masing sebanyak 7;16;16;15;16 perusahaan. Pada tahun 2016 perusahaan yang mengalami kondisi debt default meningkat drastis sebesar $128 \%$ dibandingkan tahun 2015 dan tidak menurun signifikan pada tahun 2017-2019.

Uji Kelayakan Model Regresi (Hosmer and Lemshow Goodness of Fit)

Tabel 5. Hosmer and Lemeshow Test

\begin{tabular}{|l|r|r|r|}
\hline Step & Chi-square & Df & \multicolumn{1}{c|}{ Sig. } \\
\hline 1 & 7,141 & 8 &, 522 \\
\hline
\end{tabular}

Sumber : Hasil output SPSS versi 20.0

Nilai Chi- square yang dihasilkan pada tabel diatas yaitu sebesar 7,141 serta nilai pada kolom signifikansi 0,522 , (lebih besar dari 0,05 ) artinya model regresi diterima dan fit serta layak untuk dilakukan analisis lebih lanjut.

Uji Ketepatan Prediksi (Matriks Klasifikasi)

Tabel 6. Classification Table ${ }^{\mathrm{a}}$

\begin{tabular}{|c|c|c|c|c|}
\hline & \multirow[t]{3}{*}{ Observed } & \multicolumn{3}{|c|}{ Predicted } \\
\hline & & OAGC & & Percentage \\
\hline & & $\begin{array}{c}\text { Tidak Menerima } \\
\text { OAGC }\end{array}$ & $\begin{array}{c}\text { Menerima } \\
\text { OAGC }\end{array}$ & Correct \\
\hline Step 1 & $\begin{array}{l}\text { OAGC Tidak Menerima OAGC } \\
\text { Menerima OAGC } \\
\text { Overall Percentage }\end{array}$ & $\begin{array}{r}204 \\
6\end{array}$ & $\begin{array}{l}0 \\
5\end{array}$ & $\begin{array}{r}100,0 \\
45,5 \\
97,2\end{array}$ \\
\hline
\end{tabular}

a. The cut value is, 500

Sumber : Hasil output SPSS versi 20.0

Hasil pengujian pada tabel klasifikasi diatas memperlihatkan bahwa model regresi dapat memprediksi dengan benar sebesar $97,2 \%$ dari kejadian sebenarnya atas faktor yang berpengaruh terhadap opini audit terkait going concern, dengan demikian model regresi ini layak untuk digunakan dalam memprediksi penerimaan OAGC.

Uji Koefisien Determinasi (Negelkerke $R$ Square)

Tabel 7. Hasil Uji Koefesien Determinasi

Model Summary

\begin{tabular}{|l|c|c|c|}
\hline Step & $\begin{array}{c}-2 \text { Log } \\
\text { likelihood }\end{array}$ & $\begin{array}{c}\text { Cox \& Snell R } \\
\text { Square }\end{array}$ & $\begin{array}{c}\text { Nagelkerke R } \\
\text { Square }\end{array}$ \\
\hline 1 & $51,075^{\mathrm{a}}$ &, 153 &, 461 \\
\hline
\end{tabular}

a. Estimation terminated at iteration number 8 because

parameter estimates changed by less than ,001.

Sumber : Hasil Output SPSS versi 20.0
Determinants of

Manufacturer's

Going Concern

Audit Opinions 
Determinants of Manufacturer's Going Concern Audit Opinions
Nilai Negelkerke $R$ Square yang diperoleh yaitu sebesar 0,461 atau lebih besar dari nilai Cox 7 Snell $R$ sebesar 0,153. Hasil tersebut menunjukkan variabel OAGC dapat dijelaskan oleh variabel profitabilitas, ukuran perusahaan, debt default dan audit tenure $46,10 \%$ dan sisanya sebesar $53,90 \%$ dijelaskan oleh variabel lain yang tidak digunakan dalam penelitian ini.

\section{Uji Simultan (Omnibus Test of Model Coefficients)}

Tabel 8. Uji Secara Simultan

Omnibus Tests of Model Coefficients

\begin{tabular}{|rl|r|r|r|}
\hline & & Chi-square & \multicolumn{1}{|c|}{ Df } & \multicolumn{2}{|c|}{ Sig. } \\
\hline \multirow{4}{*}{ Step 1 } & Step & 35,753 & 4 &, 000 \\
& Block & 35,753 & 4 &, 000 \\
& Model & 35,753 & 4 &, 000 \\
\hline
\end{tabular}

Sumber : Hasil output SPSS versi 20.0

Nilai Chi-square yang dihasilkan pada tabel Omnibus Tes diatas sebesar 35,753 dengan nilai sig. 0,000 $<0,05$, dengan demikian profitabilitas, ukuran perusahaan, debt default, dan audit tenure berpengaruh signifikan terhadap opini audit going concern.

\section{Uji Hipotesis}

Tabel 9. Uji Secara Parsial

Variables in the Equation

\begin{tabular}{|c|c|c|c|c|c|c|c|c|}
\hline & & B & S.E. & Wald & Df & Sig. & $\operatorname{Exp}(B)$ & Kesimpulan \\
\hline \multirow{5}{*}{ Step $1^{\mathrm{a}}$} & ROA & $-23,361$ & 8,154 & 8,207 & 1 & ,004 & ,000 & H1 : diterima \\
\hline & SIZE &,- 306 & , 102 & 9,011 & 1 & ,003 & ,737 & H2 : diterima \\
\hline & $\mathrm{DD}$ & 2,314 & ,933 & 6,155 & 1 & ,013 & 10,110 & H3 : diterima \\
\hline & AT &,- 081 & ,326 & ,061 & 1 & ,805 & ,922 & H4: ditolak \\
\hline & Constant & 5,290 & 2,885 & 3,361 & 1 & ,067 & 198,272 & \\
\hline
\end{tabular}

a. Variable(s) entered on step 1: ROA, SIZE, DD, AT.

Dari hasil pengujian pada tabel diatas dapat diperoleh persamaan regresi sebagai berikut:

$$
\operatorname{Ln} \frac{P(Y)}{1-P(Y)}=5,290-23,361(\text { ROA ) - 0,306(SIZE) + 2,314(DD) - 0,081(AT) + e }
$$

\section{Interpretasi Hasil Penelitian \\ Pengaruh Profitabilitas terhadap Opini Audit Going Concern}

Hasil pengujian atas hipotesis pertama pada tabel diatas menunjukkan bahwa variabel profitabilitas memiliki koefesien bertanda negatif sebesar -23,361 dengan taraf signifikan sebesar 0,004 (lebih kecil dari 0,05). Artinya hipotesis 1 diterima, yang mengartikan bahwa profitabilitas berpengaruh signifikan dengan arah negatif terhadap opini audit going concern. Dari hasil ini dapat disimpulkan bahwa semakin tinggi kemampuan perusahaan menghasilkan laba maka probabilitas bagi perusahaan untuk memperoleh OAGC semakin kecil. Perusahaan yang mampu menghasilkan laba mengindikasikan bahwa manajemen sudah menjalankan perusahaan dengan efektif sehingga keberlangsungan usaha perusahaan dimasa mendatang tidak diragukan.

Hasil ini konsisten dan sejalan dengan penelitian Indriastuti (2016), Rahman dan Ahmad (2018) serta Irwanto dan Tanusdjaja (2020) yang membuktikan bahwa ada pengaruh negatif profitabilitas terhadap OAGC. Namun tidak konsisten dengan hasil penelitian yang dilakukan oleh Fitriani dan Asiah (2018) yang membuktikan bahwa profitabilitas tidak berpengaruh terhadap OAGC.

\section{Pengaruh Ukuran Perusahaan terhadap Opini Audit Going Concern}

Hasil pengujian atas hipotesis kedua pada tabel diatas memperlihatkan bahwa variabel ukuran perusahaan memiliki koefesien bertanda negatif sebesar -0,306 dengan tingkat signifikan sebesar 0,003 (lebih kecil dari 0,05). Artinya hipotesis 2 diterima, yang berarti 
bahwa ukuran perusahaan berpengaruh signifikan dengan arah negatif terhadap opini audit going concern. Dari hasil penelitian ini dapat disimpulkan bahwa semakin besar ukuran perusahaan maka kemungkinan perusahaan untuk memperoleh OAGC semakin kecil. Perusahaan besar memiliki sumber daya yang lebih besar yang diharapkan dapat meminimalisasi risiko yang dihadapi perusahaan dimasa mendatang. Dengan asset yang dimiliki perusahaan besar juga dapat memperoleh kepercayaan public lebih besar dibandingkan dengan perusahaan kecil sehingga kelangsungan usaha diharapkan tetap mampu dijalankan.

Hasil ini konsisten dan sejalan dengan penelitian Widyantari \& Putri (2011) yang membuktikan bahwa ada pengaruh negatif ukuran perusahaan terhadap OAGC. Namun tidak konsisten dengan hasil penelitian Fadrul dan Wijaya (2018) yang membuktikan bahwa tidak ada pengaruh dari ukuran perusahaan terhadap OAGC.

\section{Pengaruh Debt Default terhadap Opini Audit Going Concern}

Hasil pengujian atas hipotesis ketiga pada tabel diatas variabel debt default memiliki koefesien bertanda positif sebesar 2,314 dengan tingkat signifikan sebesar 0,013 (lebih kecil dari 0,05). Artinya hipotesis 3 diterima, yang berarti bahwa debt default berpengaruh positif signifikan terhadap opini audit going concern. Dari hasil penelitian ini dapat disimpulkan bahwa perusahaan yang mengalami debt defult akan semakin besar kemungkinan untuk memperoleh opini audit going concern. Ketika perusahaan mengalamai kegagalan untuk dapat memenuhi kewajibannya itu merupakan salah satu kondisi dimana perusahaan diindikasikan dalam masa kesulitan keuangan dimana hal ini dapat menimbulkan keraguan auditor terhadap keberlangsungan usaha perusahaan dimasa mendatang sehingga hal ini dapat meningkatkan kemungkinan auditor independen untuk memberikan opini audit going concern.

Hasil ini konsisten dan sejalan dengan penelitian Izazi dan Arfianti (2019), Dewi dan Latrini (2018) serta Kesumojati, Widyastuti dan Darmansyah (2017) yang membuktikan bahwa ada pengaruh positif debt default terhadap OAGC. Namun tidak konsisten dengan Putri, Hardiwinoto dan Alwiyah (2018) yang membuktikan bahwa debt default tidak berpengaruh terhadap OAGC.

\section{Pengaruh Audit Tenure terhadap Opini Audit Going Concern}

Hasil pengujian atas hipotesis keempat pada tabel diatas variabel audit tenure memiliki koefesien bertanda negatif sebesar -0,081 dengan tingkat signifikan sebesar 0,805 (lebih besar dari 0,05$)$. Artinya hipotesis 4 ditolak, yang berarti bahwa audit tenure tidak berpengaruh signifikan terhadap OAGC. Dari hasil penelitian ini dapat disimpulkan bahwa lamanya perjanjian pelaksanaan audit antara perusahaan dengan KAP yang sama tidak mempengaruhi independensi auditor dalam memberikan opini audit going concern terhadap perusahaan.

Hasil ini konsisten dan sejalan dengan penelitian Putri dan Fettry (2017) yang membuktikan bahwa tidak ada pengaruh audit tenure terhadap OAGC. Namun tidak konsisten dengan Ariska, Maslichah dan Afifudin (2019) yang membuktikan bahwa ada pengaruh positif audit tenure terhadap OAGC.

\section{PENUTUP}

Berdasarkan hasil dan pembahasan penelitian diatas, maka dapat ditarik kesimpulan sebagai berikut:

1. Profitabilitas berpengaruh negatif terhadap opini audit going concern,

2. Ukuran Perusahaan berpengaruh negatif terhadap opini audit going concern,

3. Debt Default berpengaruh positif terhadap terhadap opini audit going concern, dan

4. Audit Tenure tidak berpengaruh terhadap opini audit going concern
Determinants of Manufacturer's Going Concern Audit Opinions 
Determinants of Manufacturer's Going Concern Audit Opinions

252

\section{DAFTAR PUSTAKA}

Ariska, E.Y., Maslichah \& Afifudin. 2019. Pengaruh Audit Tenure, Opinion Shooping, Leverage, dan Pertumbuhan Perusahaan terhadap Penerimaan Opini Audit Going Concern. E-JRA Vol.08, No. 06, Agustus 2019, hal.157-170.

Dewi, I.D.A.N.S. dan Latrini, M.Y. 2018. Pengaruh financial distress dan debt default pada opini audit going concern. E-jurnal akuntansi universitas udayana Vol. 22 No.2, hal.1223-1252

Fadrul dan Wijaya, Y. 2018. The effect of Liquidity, Size and Company Growth on Going Concern Audit Opinion For Companies Listed on Indonesia Stock Exchange. BILANCIA Vol. 2 No. 3, September 2018, hal. 310-321

Fitriani dan Asiah, A. N. 2018. Pengaruh Profitabilitas, Likuiditas dan Ukuran Perusahaan terhadap Opini Audit Going Concern. Jurnal Manajemen dan Akuntansi Vol. 19, No. 2, Oktober 2018, hal. 31-40

Ghozali, I. 2016. Aplikasi Analisis Multivariate dengan program IBM SPSS 23. Badan Penerbit Universitas Diponegoro, Semarang.

Indriastuti, M. 2016. Pengaruh Profitabilitas dan Likuiditas terhadap Penerimaan Opini Audit Going Concern. Fokus Ekonomi, Vol. 11 No. 2, Desember 2016, hal.37-50

Irwanto, F. dan Tanusdjaja, H. 2020. Pengaruh Profitabilitas, Likuiditas dan Solvabilitas terhadap Opini Audit terkait Going Concern. Jurnal Multiparadigma Akuntansi Tarumanegara, Vol. 2 No. 1, Januari 2020, hal.298-307

Izazi, D. dan Arfianti, R. I. 2019. Pengaruh Debt Default Financial Distress, Opinion Shopping dan Audit Tenure terhadap Opini Audit Going Concern. Jurnal Akuntansi Vol. 8, No. 1, Februari 2019, hal. 1-14.

Kasmir. 2018. Analisis Laporan Keuangan. Jakarta: PT Rajagrafindo Persada.

Kesumojati, S.C.I., Widyastuti, T., dan Darmansyah. 2017. Pengaruh Kualitas Audit, Financial Distress, Debt Default terhadap Penerimaan Opini Audit Going Concern. Jurnal Ilmiah Akuntansi Fakultas Ekonomi Vol. 3 No. 1, hal. 62-76

Minerva, L., \& dkk. (2020). pengaruh kualitas audit, debt ratio, ukuran perusahaan, dan audit lag terhadap penerimaan audit going concern. Riset dan jurnal akuntansi 4(1), hal.254-266

Putri, Y.D., Hardiwinoto., dan Alwiyah. 2018. Pengaruh Ukuran Perusahaan, Debt Default, Opini Audit Tahun Sebelumnya dan Pertumbuhan Perusahaan terhadap Penerimaan OPini Audit Going Concern. Maksimum Media Akuntansi Universitas Muhammadiyah Semarang, Vol. 9, No. 1, hal. 63-80

Rahman, M.A. dan Ahmad, H. 2018. Pengaruh Likuiditas, Profitabilitas dan Solvabilitas terhadap Opini Audit Going Concern. Center of Economic Student Journal, Vol. 2 No. 1, Juli 2018, hal.44-55

Sari, P. C., 2020. Pengaruh Audit Lag, Profitabilitas dan Likuiditas terhadap Opini Audit Going Concern pada Perusahaan Manufaktur yang Terdaftar di Bursa Efek Indonesia. Jurnal Riset Akuntansi Warmadewa, 1(1), hal.1-7.

Suharsono. (2018). Pengaruh kualitas audit, debt default, dan pertumbuhan perusahaan terhadap penerimaan opini audit going concern. Jurnal ilmiah ilmu akuntansi, keuangan dan pajak 2(1), hal.35-48

Syahputra, F., \& Yahya, R. (2017). Pengaruh audit tenure, audit delay, opini audit tahun sebelumnya dan opinion shopping terhadap penerimaan opini audit going concern. Jurnal Ilmiah Mahasiswa Ekonomi Akuntansi 2(3), hal.39-47.

Widyantari dan Putri, A.A.A. 2011. "Opini Audit Going Concern dan Faktor-Faktor yang Memengaruhi: Studi pada Perusahaan Manufaktur di Bursa Efek Indonesia". Thesis S2, Universitas Udayana, Denpasar 